\title{
Institutional Ownership, Characteristics of the Audit Committee and Information Power Earnings
}

\author{
I Nyoman Wijana Asmara Putra and Ni Made Dwi Ratnadi \\ Faculty of Economic and Business, University Udayana, Jimbaran, Bali \\ Wijana_putra@yahoo.co.id
}

\begin{abstract}
The objective of this research to test the effect of institusional ownership and committee audit characteristic on the informativeness of earnings. Especially this research to test the non-banking institusional ownership, banking institusional ownership, independent commissioner as the member of audit committee, competence a member audit commitee in accounting and financial, and frequency of meeting held by audit committee. The data is taken from secondary sourced from the Indonesian Stock Exchange. Data were analyzed using multiple regression. The result indicates that, the non-banking institutional ownership, and shareholding by banks positive effect on the informativeness of earnings. Competence audit committee members in the fields of accounting and finance, and frequency of meetings held positive effect on informativeness of earnings. However, the proportion of independent directors on the audit committee does not affect to the earnings informativeness.
\end{abstract}

Keywords: institutional ownership, audit committee earnings informativeness

\section{INTRODUCTON}

Separation of company ownership and management can cause agency problems between management and external shareholders. This occurs because of differences in interests between management and external shareholders. Management may be able to choose accounting methods and establish accrual recognition policies. This management action aims to signal to outsiders that managers have private information or intentionally opportunistic behavior to manipulate earnings. The manager's behavior can result in low earnings information power. The quality of earnings can be increased and the interests between management and shareholders can be harmonized, if the share ownership by management is increased.

Feng et al., (2011) test earnings quality in developing companies, proving that there is a positive correlation between share ownership by management and the content of earnings information. However, if the percentage of share ownership by management is high, it can reduce earnings information power. This is evidenced by Yeo et al., (2002) by examining companies listed on the Singapore Stock Exchange and Gabrielsen et al. (2002) show that the higher the proportion of share ownership by management, causing the information content of corporate profits to be low.

One way that can be used to monitor management is to avoid opportunistic behavior through institutional ownership of shares (institutional ownership). Institutional monitoring activities can change and influence company management to present quality earnings information. Shabbir (2012) proves that monitoring conducted by institutions can substitute the costs of debt agencies so that costs are reduced, and the value of the company increases because the quality of earnings is high. 
Institutional ownership does not always increase the value of the company or present quality profits; institutional ownership can reduce the value of the company when institutional interests are in line with the interests of managers (Hsu and Wang, 2014). This happens when institutions and managers share the same interests so that they collude eventually resulting in decreased quality of earnings.

Fan and Wong (2002) examined the effect of ownership structure on earnings information power in seven East Asian countries including Indonesia. Public companies in Indonesia have a concentrated ownership structure in the majority shareholders. Fan and Wong (2002) prove that ownership concentration in the ultimate controlling shareholder causes low earnings information power. This shows the existence of expropriation of minority shareholders (Ratnadi et al., 2013; Liris, 2013)

The expropriation of minority shareholders is most likely to occur in countries that adopt Civil Law such as in Indonesia. There are differences in the relevance of the value of accounting information between countries with the legal system of common law and civil law. The relevance of value to profits is stronger in countries that implement legal systems based on the common law rather than civil law (Subekti, 2012). This relates to investor demand for timely financial accounting information and better investor protection in the common law legal system (Putra, 2008). Indonesia is a country that applies the civil law. One of the characteristics of a country that implements the civil law is the protection of external investors in a weak capital market. The impact of the application of civil law on accounting applications is that there is a great opportunity for controlling shareholders to regulate transactions that are "unfair" that will harm minority or non-controlling shareholders as disclosed by Gul and Wah (2005), Wiranata and Nugrahanti (2013), Wawo (2010), Jao and Pagalung (2011). Therefore, a body is needed that can ensure that the negative influence of the concentrated ownership structure on the level of informativeness does not occur, an audit committee is formed. Woidtke and Yeh (2013) state that the financial crisis in Asia has led to an emphasis on independent board of directors and a more stringent supervisory role. The establishment of an audit committee, especially an independent audit committee, is a top priority for policymakers to reduce information asymmetry between controlling shareholders and other investors. This shows a significant relationship between the audit committee and the quality of accounting information from an investor perspective (Amin, 2016).

Based on this explanation the purpose of this study (1) is to empirically examine the effect of nonbank institutional ownership on earnings information power, (2) to examine empirically the effect of bank ownership on earnings information power. (3) to examine empirically the influence of the composition of the audit committee on earnings information power. (4) to examine the effect of audit committee competence on earnings information power. (5) to test the frequency of meetings conducted by the audit committee on earnings information power.

\section{THEORITICAL REVIEW}

The cornerstone of the theory underlying this research is agency theory. Agency theory explains that corporate management is often left to professional managers who are not owners of the company. The relationship between the manager and the owner of the company is called the agency relationship. Jensen and Meckling (1976) stated that agency relationships arise when one or more individuals (principals) pay other individuals 
(agents) to act on their behalf and delegate the power to make decisions. The main goal that must be achieved by the agent is to maximize the prosperity of the company owner. The owner gives the agent the power and authority to make the best decision that benefits the owner of the company (shareholders). Increase shareholder prosperity by increasing the value of the company as the company's main goal, while the company's management also wants to increase its prosperity in person. This creates a conflict of interest between the manager and shareholders.

Conflicts of interest between managers and shareholders can be minimized by a supervisory mechanism that can align the related interests, but with the emergence of the supervision mechanism, it will cause costs called agency costs. Agency problems between potential shareholders and managers occur if the manager does not own the company's shares. Shareholders certainly want managers to work with the aim of maximizing shareholder prosperity. On the contrary, company managers can act not to maximize shareholder prosperity but have an interest in individual prosperity. To ensure that managers work earnestly for the benefit of shareholders, costs must be incurred, called agency costs. These costs include expenditures to monitor the activities of managers, expenditures to create an organizational structure that minimizes the actions of managers who are not desirable, as well as opportunity, lost arising due to conditions where managers cannot immediately take decisions without the approval of shareholders (Jensen and Meckling, 1976).

There are several alternatives to reduce agency costs, namely (1) increase share ownership by management. This ownership will align management interests with shareholders (Jensen and Meckling, 1976). (2) By increasing the dividend payout ratio, there is not enough free cash flow available. (3) increase funding with debt. (4) Institutional investors as monitoring agents. Moh'd et al. (1998) states that the distribution of shares between external shareholders, namely institutional investors and dispersion shareholders can reduce agency costs. This can happen because ownership represents a source of power (source of power) that can be used to support or oppose the existence of management (Salehi et al., 2011; Shabbir, 2012). Ownership by institutional investors such as insurance companies, banks, investment companies or other institutions can encourage more optimal supervision of management performance so that the information power of earnings increases.

The Audit Committee is a group of people selected from the company's board of commissioners who are responsible for assisting the auditor in maintaining independence from management. According to the forum for Corporate Governance in Indonesia-FCGI (2003) the definition of an audit committee is a committee that receives a delegation of duties of the board of commissioners because the delegation of authority is useful in carrying out the work of the board of commissioners in detail by focusing the attention of the board of commissioners on the specific field of the company or the implementation of good corporate Governance by management The audit committee is a committee formed by the board of commissioners to carry out the supervisory duties of the management of the company. The audit committee is considered as a liaison between shareholders and the board of commissioners with the management in handling control issues (Bayrakdaroglu, 2012).

The main objective of establishing an audit committee within a company is to increase the effectiveness, accountability, transparency, and objectivity of the board of commissioners and the board of directors. The benefits of the existence of an audit 
committee for the company are (1) Improving the quality of financial reporting, (2) Allowing the board of commissioners to provide an independent assessment of the company's financial performance, (3) Strengthening the position of the external auditor in providing recommendations for improvement, (4) Strengthening independence and objectivity internal auditor, (5) Increasing public confidence, especially investors towards the company. The Audit Committee is responsible for giving opinions to the board of commissioners on reports or matters that require the attention of the board of commissioners and carrying out other duties related to the duties of the board of commissioners (Bapepam, 2004). In general, the audit committee has duties and responsibilities in the areas of financial reporting, corporate governance and corporate supervision (Mohammed et al., 2011). For the audit committee communication with various parties to run smoothly, the qualifications of the audit committee members are independent, understand business activities, have communication and vigilance skills. Audit committee members, in addition, must be experts in their fields are also required to know and master the field of accounting and auditing, financial statement analysis, corporate spending, information management systems, systems, and corporate controls and responsive to all developments (Nugroho, 2012; Prastiti, 2013).

Membership of the audit committee consists of at least three members, one of whom is an independent commissioner of the company who simultaneously serves as chairman of the audit committee. While other members are independent external parties, at least one of them has the ability in accounting and or finance. The audit committee in the team has at least enough competence and experience regarding auditing, accounting, and finance, regulations and legislation, related industrial processes. With the existence of these three competencies, it is expected that the audit committee can proactively and evaluatively review all the important matters of the company's financial reporting in a very short time, namely at work meetings ranging from two to three hours each meeting and amounting to four to six meetings each year.

The quality of accounting information can be measured in several ways, one of which is by looking at the information power of the numbers presented in the financial statements of capital market measures (Hasan and Shadu, 2013). This is based on market efficiency (market efficiency), measured by how far the prices of securities deviate from their intrinsic value (Hartono, 2005). An efficient market according to this concept is a market whose security values do not deviate from its intrinsic values. Fama (1985) in Hartono (2005) defines a securities market as efficient if securities prices reflect in full the information available (a security market is fully reflecting the information available). Information efficiency in the form of information is half strong and in a decision tested by looking at abnormal returns (abnormal returns) that occur.

One study that looks at the power of accounting information in Indonesia is Gideon's (2005) research. The results show that explanatory power of accounting numbers is book value per share and residual earnings per share. Naimah and Utama (2006); He et al. (2013) prove that the book value of equity and accounting profit has a significant positive relationship to stock prices and earnings information power.

Hypothesis. Blume and Kein (2012); Alfaraih et al., (2012) and Tahir et al., (2015) prove that institutional ownership has a positive effect on stock prices because institutional investors get more information than individual investors, this can reduce the opportunity for management to manage accruals. Douthett and Jung (2001) prove that corporate 
shareholders belonging to the keiretsu group increase earnings information power. Yeo et al. (2000) stated that external ownership of shares that are not related to blocking holdings has a positive effect on earnings information power, this is consistent with the monitoring role of majority shareholders in management.

Based on this, the hypothesis 1 states:

H1: The higher proportion of share ownership by nonbank institutional shareholders causes higher earnings information power.

Banks are identical with sophisticated investors. Banks have advantages in obtaining and processing information compared to other investors and can monitor management, to reduce management opportunities to manipulate earnings. Also, the existence of bank investors also reduces information asymmetry because banks are superior in gathering information (Diamond, 1984; Fama, 1985; and Leland and Pyle, 1997). Fama (1985) states that banks as shareholders have access to internal information, while shareholders by the public depend on the information published by the company. Because banks are easier to access information, banks can monitor the availability and quality of the information. Datta et al. (1998) prove that banks use their control rights as shareholders in every decision made by the company such as control in financing a projector control about how the company overcomes financial difficulties. Based on this, hypothesis 2 is formulated as follows.

H2: The higher the proportion of share ownership by the Bank, causing higher earnings information power.

There are three characteristics of the audit committee, namely the independent director in the audit committee, the member of the audit committee with competence in the accounting and finance fields and the frequency of the audit committee to hold a meeting in one year. The existence of an independent director in the audit committee can solve the conflicts that occur between internal managers (Fama and Jensen, 1983; Hasan et al., 2012; Habbash et al., 2013). Empirical evidence shows that independent directors can reduce financial reporting problems and reduce earnings management (McMullen and Raghunandan, 1996). The study proves that independent directors in the audit committee can reduce agency conflicts and can effectively monitor the financial reporting process so that companies can present quality financial reports. Thus the third hypothesis is formulated as follows.

H3: The proportion of independent directors in the audit committee has a positive effect on earnings information power.

Rose and Rose (2008) and Dickins et al. (2009) asserted that competence in the financial field is very important to be owned by members of the audit committee. Competencies in the field of finance owned by the audit committee can reduce earnings management (Bedard et al., 2004) and companies are more conservative in reporting earnings (Krishnan and Visvanathan, 2009). If the audit committee member has competencies in accounting and finance, then the process of preparing financial reporting can be monitored so that the financial statements presented have more accounting information power. Based on this, hypothesis 4 is presented as follows.

H4: The greater the proportion of audit committee members who have competence in accounting and finance, the better the earnings information power.

The frequency of meetings conducted by the audit committee indicates that the audit committee is diligent/diligent in resolving problems and responding to current issues relating to the auditor at formal meetings. Raghunandan and Rama (2007) stated that the 
frequency of meetings reflected the activeness of audit committee members. El-Faitouri (2014) proved that the frequency of meetings conducted by the audit committee could reduce the cost of debt and reduce fraud. This means that audit committee members who often hold meetings tend to be able to improve the quality of financial reports. Hypothesis 5 is as follows.

H5: The frequency of meetings conducted by audit committee members has a positive effect on earnings information.

\section{METHOD}

The population of this study were all companies listed on the Indonesia Stock Exchange in a row from 2010 to 2015 . The sample was determined by non probality sampling method with purposive sampling technique. The sample criteria are the manufacturing sector. This is because the manufacturing industry sector cannot be compared with the financial industry sector. The financial industry sector has a different nature of ownership and financial statement structure from companies in other industrial sectors. The valuation ratio for financial companies is not comparable to companies other than the financial sector (LaPorta et al., 2002).

Data collection techniques are archival or documentation data collection techniques. One form of archive data collection is secondary data. Secondary data in the study were obtained from annual reports and stock market price data at the end of 2011-2015. Based on the sources, data was collected from the Indonesian Capital Market Directory (ICMD) and from the Indonesia Stock Exchange, with accusations at www.bei.co.id

Dependent variable in this study is earnings information power is the information content of earnings as measured by looking at the relationship between earnings value and the value of stock returns at the beginning of the year with a formula like the following.

$\mathrm{AR}_{\mathrm{j}, \mathrm{t}}=\mathrm{R}_{\mathrm{j}, \mathrm{t}}-\mathrm{Rm}_{\mathrm{t}}$

Information:

$\mathrm{AR}_{\mathrm{j}, \mathrm{t}}$ : abnormal return of company $\mathrm{j}$ on month $\mathrm{t}$.

$R_{\mathrm{j}, \mathrm{t}}$ : $\quad$ return $\mathrm{j}$ securities on month $\mathrm{t}$.

$\mathrm{Rm}_{\mathrm{t}}$ : return market index on month $\mathrm{t}$

The accumulation of abnormal returns is calculated using the following model.

$$
C A R_{t 1-t 5}=\sum_{t 1}^{t=5} A R_{j t 1-j t 5}
$$

Information:

CAR: cumulative abnormal return $1^{\text {st }}$ year to $5^{\text {th }}$ year.

$t_{1}-t_{5}$ : the length of the observation interval of stock returns or the accumulated period of $t_{1}$ to $t_{5}$.

Independent variables are:

1) Institutional ownership (KI) is ownership of company shares by institutions other than banks measured by the percentage of share ownership.

2) Bank Ownership (KB) is the percentage of shares owned by a bank.

3) The composition of the Audit Committee (KAK) is the number of independent directors divided by the total director on the audit committee 
4) Audit Committee Competency (KAF) is a percentage of audit committee members who have expertise in accounting and finance for the total members of the audit committee.

5) The number of audit committee meetings (KAR) is the frequency of meetings conducted by the audit committee in one year.

This study also includes a company growth control variable (Q) as measured by a market to book ratio (MTB). This variable is intended to control the influence of the company's growth on the stock profit-return relationship. Corporate growth is positively correlated with the future earnings persistence.

The data analysis technique used in this study is multiple linear regression with a formula like the following.

$$
\mathrm{CAR}_{\mathrm{it}}=\alpha+\beta_{1} \mathrm{KI}_{\mathrm{it}}+\beta_{3} \mathrm{~KB}_{\mathrm{it}}+\beta_{4} \mathrm{KAK}_{\mathrm{it}}+\beta_{5} \mathrm{KAF}_{\mathrm{it}}+\beta_{6} K A R_{i t}+\beta_{7} Q_{i t}+\varepsilon_{\mathrm{it}}
$$

Keterangan:

$\mathrm{KI}_{\text {it }}$ : $\quad$ Percentage of institutional ownership other than bank $\mathrm{i}$ in year $\mathrm{t}$

KBit: $\quad$ Percentage of Ownership by the Bank

$\mathrm{KAK}_{\mathrm{it}}$ : Percentage of independent directors as audit committee of company $\mathrm{i}$ in year $\mathrm{t}$

$\mathrm{KAF}_{\text {it }}$ : The percentage of audit committee members has competence in the field of accounting and finance

$\mathrm{KAR}_{\text {it }}$ : Number of meetings conducted by the audit committee for one year.

$\mathrm{Q}_{\mathrm{it}}$ : $\quad$ Comparison between equity market prices and book value of total assets at the end of the year.

$\beta_{1-} \beta_{6}: \quad$ The coefficient of each variable.

$\alpha: \quad \quad$ constant

eit : $\quad$ Error term of company $\mathrm{i}$ in year $\mathrm{t}$

So that the results of data analysis with the regression model are not biased, the classical assumptions are tested before hypothesis testing. The hypothesis is accepted or rejected by looking at the significance value of t. The hypothesis is accepted if the probability value ( $\mathrm{p}$-value) is $\leq 0,05$.

\section{RESULTS AND DISCUSSION}

Before testing the hypothesis, it is first explained about the research variables, both dependent and independent variables. Earnings information power is measured by using cumulative abnormal return (CAR), which is the earnings information content measured by looking at the relationship between earnings value and stock return value at the beginning of the year. Institutional ownership (KI) is ownership of company shares by institutions other than banks measured by the percentage of share ownership. Bank Ownership (KB) is the percentage of shares owned by a bank. The composition of the audit committee (KAK) is the number of independent directors divided by the total directors on the audit committee. Audit Committee Competency (KAF) is a percentage of audit committee members who have expertise in accounting and finance for the total members of the audit committee. The number of audit committee meetings (KAR) is the frequency of meetings conducted by the audit committee every year and $Q$ is the 
company's value as measured by the ratio of market value to the book value of the company. Table 1 presents a description of the research variables as follows.

Table 1. Descriptive Statistics Test Results

\begin{tabular}{|c|c|c|c|c|c|}
\hline Variable & $\begin{array}{l}\text { Number of } \\
\text { Samples }\end{array}$ & $\begin{array}{l}\text { Minimal } \\
\text { Value }\end{array}$ & $\begin{array}{l}\text { Average } \\
\text { value }\end{array}$ & $\begin{array}{l}\text { Maximum } \\
\text { value }\end{array}$ & $\begin{array}{l}\text { Standard } \\
\text { Deviation }\end{array}$ \\
\hline CAR & 126 & $-0,290$ & 0,434 & 2,690 & 0,378 \\
\hline KI & 126 & 0,015 & 0,417 & 0,840 & 0,172 \\
\hline KB & 126 & 0 & 0,057 & 0,572 & 0,139 \\
\hline KAK & 126 & 0,250 & 0,367 & 1 & 0,138 \\
\hline KAF & 126 & 0,200 & 0,545 & 0,800 & 0,182 \\
\hline KAR & 126 & 4 & 7,772 & 18 & 3,884 \\
\hline Q & 126 & 0,060 & 3,745 & 252 & 22,435 \\
\hline
\end{tabular}

The average CAR value is 0.434 , this shows that manufacturing companies have a positive accumulation of abnormal returns. The average non-banking institutional ownership of shares is 41.70 percent, the largest institutional ownership is 84.40 percent. The share of manufacturing companies owned by the Bank averages 5.70 percent. Share ownership by the largest bank is 57.20 percent. On average 36.70 percent of independent directors served as audit committees. A total of 54.50 percent of audit committee members have competencies in the field of accounting and finance. The average audit committee holds meetings almost 8 times a year.

The classic assumption test in this study consisted of multicollinearity test, heteroscedasticity, autocorrelation, and normality of predictive residual values. Table 2 presents information on classical assumption tests.

Table 2. Classical Assumption Test Results

\begin{tabular}{lccccc}
\hline \multirow{2}{*}{ Information } & \multicolumn{2}{c}{ Multicollinearity Test } & \multicolumn{2}{c}{$\begin{array}{c}\text { Heteroscedasticity } \\
\text { Test }\end{array}$} & \multirow{2}{*}{$\begin{array}{c}\text { Normality } \\
\text { test }\end{array}$} \\
\cline { 2 - 5 } & Tolerance & VIF & t & Sig. & \\
\hline KI & 0,954 & 1,048 & 1,643 & 0,144 & \\
KB & 0,951 & 1,051 & 1,470 & 0,114 & \\
KAK & 0,942 & 1,061 & 1,594 & 0,550 & \\
KAF & 0,964 & 1,037 & 0,597 & 0,928 & \\
KAR & 0,965 & 1,036 & 0,521 & 0,603 & \\
Q & 0,994 & 1,006 & 0,634 & 0,527 & \\
Kolmogorov-Smirnov Z & & & & & 1,068 \\
Asymp.Sig. (2-tailed) & & & & & 0,204 \\
\hline
\end{tabular}

Multicollinearity test is carried out if there is more than one independent variable because the probability between independent variables is significant (significant) correlation. This study uses a variance inflation factor (VIF) approach to detect multicollinearity problems. The cut off value commonly used to indicate the presence of multicollinearity is the tolerance value $\leq 0.10$ or equal to the VIF value $\geq 10$. Based on the information in Table 2, the tolerance coefficient of the independent variable is greater than 0.1 and the VIF value is below 1 . The heteroscedasticity test aims to find out whether the regression model occurs from residual variance inequality one observation to another observation. If the variance from residual one observation to another observation remains, 
then it is called homokedastisitas and if different is called heteroscedasticity. Testing uses the Glejser model. Table 2 shows that all variables are not significant, thus the data is free from the problem of heteroscedasticity. Normality test is a test to find out the normality of residuals. If the residual is not normally distributed, the consequences of the t-test to see the significance of the independent variable to the dependent variable cannot be applied. This study uses the Kolmogorov-Smirnov method to test the normality of the regression model. The residual value is normally distributed if the significance level or asymp.sig (2tailed) is greater than $\alpha=5$ percent.

After the model has passed the classical assumption test, it is followed by testing the research hypothesis. The accuracy of the sample regression function in estimating the actual value can be measured from the goodness of fit. Statistically, it can be measured by the coefficient of determination, the statistical value $\mathrm{F}$ and the statistical value $t$. The results of multiple linear regression testing are shown in Table 3.

Table 3. Multiple Linear Regression Test Results

\begin{tabular}{|c|c|c|c|c|c|}
\hline & \multicolumn{2}{|c|}{$\begin{array}{c}\text { Unstandardized } \\
\text { Coefficients }\end{array}$} & \multirow{2}{*}{$\begin{array}{c}\text { Standardized } \\
\text { Coefficients } \\
\beta\end{array}$} & \multirow[b]{2}{*}{ p-value } & \multirow{2}{*}{ Significance } \\
\hline & $\beta$ & $\begin{array}{c}\text { Std } \\
\text { Error }\end{array}$ & & & \\
\hline Constant & 0,530 & 0,209 & - & 0,253 & 0.800 \\
\hline KI & 0,596 & 0,246 & 0,332 & 1,820 & 0.049 \\
\hline $\mathrm{KB}$ & 0,853 & 0,304 & 0,461 & 3,643 & 0.000 \\
\hline KAK & 0,197 & 0,307 & 0,057 & 0,643 & 0.522 \\
\hline KAF & 0,123 & 0,231 & 0,047 & 0,532 & 0.036 \\
\hline KAR & 0,004 & 0,011 & 0,032 & 0,359 & 0,045 \\
\hline Q & 0,000 & 0,002 & 0,011 & 0,013 & 0.902 \\
\hline Adjusted $R^{2}$ & 0,144 & & & & \\
\hline$F$-test & 2,559 & & & & \\
\hline Sig. & 0,000 & & & & \\
\hline
\end{tabular}

Table 3 informs that the coefficient of determination (adjusted R2) is 14.4 percent earnings information power is explained by institutional nonbank ownership variables, ownership by banks, independent commissioners as members of the audit committee, audit committee competence in accounting and finance, frequency of audit committee meetings and company value. The significance value of $F$ is 0,000 smaller than $\alpha=0,05$, thus the regression model is fit.

Hypothesis 1 (H1). The higher proportion of share ownership by institutional shareholders other than banks causes higher earnings information power. The analysis results show that hypothesis 1 is supported. Institutional shareholders have an incentive to closely monitor management and demand effective mechanisms to ensure corporate governance is implemented (Shleifer and Vishny, 1997). Institutional shareholders have sufficient resources to conduct tighter supervision than individual shareholders. The findings of this study are in line with Thanatawee (2014) which proves that institutional ownership has a positive effect on stock prices because institutional investors get more information than individual investors. This can reduce opportunities for management to manage accruals. Company shareholders who belong to the keiretsu group can increase earnings information power (Douthett and Jung, 2001). In addition, Yeo et al. (2002) state 
that share ownership by external parties not related to blocking holdings, has a positive effect on earnings information power, this is consistent with the monitoring role of majority shareholders in management.

Hypothesis 2 (H2). The higher the proportion of share ownership by the Bank, the higher the earnings information power. The analysis results show that hypothesis 2 is supported. Banks are identical with sophisticated investors. Banks have the advantage of obtaining and processing information compared to other investors and can monitor management, so as to reduce management opportunities to manipulate earnings. In addition, the existence of bank investors is also able to reduce information asymmetry because banks are superior in gathering information (Diamond, 1984; Fama, 1985; and Leland and Pyle, 1997). Fama (1985) states that banks as shareholders have access to internal information. However, shareholders by the public depend on information published by the company (Wang et al., 2014). Because banks are easier to access information, banks can monitor the availability and quality of the information. Datta et al. (1999) prove that banks use their control rights as shareholders in every decision made by the company such as control in financing a project or control about how the company deals with financial difficulties.

Hypothesis 3 (H3). The proportion of independent directors in the audit committee has a positive effect on earnings information power. The analysis results show that hypothesis 3 is not supported. The Forum for Corporate Governance in Indonesia-FGCI (2003) states that the independence of the Board of Commissioners in Indonesia is highly doubtful given the position of members of the Board of Commissioners is given as a mere sense of appreciation or based on family relationships or close relationships. In the payroll, the Board of Commissioners is based on a percentage of the salary of the Board of Directors. Therefore, the existence of an independent committee is essential for the interests of stakeholders, especially the interests of protected minority shareholders. The members of the Audit Committee are required to come from an independent external company, which must consist of independent individuals who are not involved with the day-to-day tasks of the management who manage the company and have the experience to carry out the supervisory function effectively. One of the main reasons for this independence is to maintain the integrity and an objective view of the report and the preparation of recommendations submitted by the Audit Committee (Sun and Guoping, 2013). Independent individuals tend to be more just and impartial and objective in handling a problem. Membership of the Audit Committee consists of at least 3 (three) members. One of them is an independent commissioner who concurrently serves as chairman of the audit committee. While other members are independent external parties where at least one of them has the ability in accounting and or finance. Conversely, a larger audit committee may be a form of inefficient governance (Gugong et al., 2014). Having more members can lead to a variety of more tangible perspectives in the discussion. The internal audit committee acts to oversee the management of the company so that it is better by reviewing financial information such as financial statements so that it can help management take action to prevent various risks. Therefore, the effectiveness of the audit committee is associated with the prosperity or financial difficulties of the company in accordance with the results of Widyati's research (2013) found that the audit committee does not affect the company's financial performance. 
Hypothesis 4 (H4). The greater the proportion of audit committee members who have competence in accounting and finance, the better the earnings information power. The analysis results show that hypothesis 4 is supported. The presence of an accounting or financial expert in the audit committee relates to fewer financial reporting errors (Dechow et al., 1996). Raghunandan and Rama (2007). The presence of an independent audit committee is more effective in facilitating monitoring of financial reporting compared to external auditors (Beasley (1996); Dechow et al., 1996; Prastiti and Wahyu, 2013) The empirical relationship between the audit committee and monitoring is explained by agency theory, which states that the committee an independent audit provides effective oversight of management. The audit committee serves to provide views on issues related to fiscal policy, accounting and internal control. The purpose of the audit committee formation (KNKG, 2006) is to ensure that the financial statements issued are not misleading and in accordance with generally accepted accounting practices, ensuring that internal controls are adequate, following up on alleged financial deviations and legal implications and recommending external auditor selection.

Hypothesis 5 (H5). The frequency of meetings conducted by audit committee members has a positive effect on earnings information. The results of the analysis state that hypothesis 5 is supported. The Audit Committee will hold periodic meetings and can hold additional meetings or special meetings if needed. This periodic meeting as determined by the Audit Committee itself and carried out at least the same as the provisions of the board of commissioners meeting specified in the articles of association of the company. The Audit Committee usually needs to hold meetings three to four times a year to carry out their obligations and responsibilities regarding the financial reporting system (FCGI, 2003). The Audit Committee can also hold executive meetings with parties outside of the Audit Committee's membership who are invited according to the requirements or periodically. The outside parties included the commissioners, senior management, the head of the internal auditor and the head of the external auditor. The results of the Audit Committee meeting are set forth in the minutes of the meeting signed by all members of the Audit Committee. The Chair of the Audit Committee is responsible for the agenda and supporting materials needed and is obliged to report the activities of this Audit Committee meeting to the board of commissioners.

Bapepam (2004) requires that the audit committee held a meeting at least equal to the provisions of the minimum board of commissioners meeting stipulated in the Budget. Beasley (2004) found that corporate audit committees that make errors in financial reporting have fewer meetings than corporate audit committees that do not make mistakes in financial reporting. Xie et al. (2003) report that the number of audit committee meetings is negatively related to the level of earnings management. The research indicates that the audit committee that meets regularly becomes a better supervisor in overseeing the financial reporting process.

The firm value control variable is proxied by the company's growth, measured by the ratio of market prices to the book value does not affect earnings information power. These results indicate that the value of the company is not able to control the influence of institutional ownership variables other than banks, share ownership by banks, audit committee members' potential in accounting and finance and the frequency of meetings conducted by the board of commissioners on earnings information. 


\section{CONCLUSION}

Based on the results of the analysis that has been done it can be concluded that nonbank institutional ownership and share ownership by banks have a positive effect on earnings information power. Shareholders by institutions, including banks, are sophisticated shareholders and have the advantage of accessing information and being able to monitor company management, thereby reducing management opportunities in manipulating profits. The proportion of independent commissioners as audit committees has no effect on earnings information power. Audit committee competence in accounting and finance has a positive effect on earnings information power. The frequency of meetings conducted by the audit committee for one year has a positive effect on earnings information power.

Suggestion. This study uses manufacturing companies as samples, to avoid any industry effects on earnings information power. Researchers are then advised to use a type of industry other than manufacturing to test the consistency of research results. This research uses only two components of corporate governance, namely institutional ownership and audit committee, the next researcher uses a corporate governance index as an explanation of earnings information power.

\section{REFERENCES}

Alfaraih, M., Alanezi, F.dan Almujamed, H. (2012). "The Influence of Institutional and Government Ownership on Firm Performance: Evidence from Kuwait". International Business Research, 5 (10), 192- 200

Amin, A. (2016). "Independensi Komite Audit, Kualitas Audit dan Kualitas Laba: Bukti Empiris Perusahaan dengan Kepemilikan Terkonsentrasi”. Jurnal Akuntansi dan Keuangan. 18(1), 1-14.

Bapepam. (2004). Keputusan Bapepam No. IX.1.5. Pembentukan dan Pedoman Pelaksanaan Kerja Komite Audit. Diunduh bulan Juli 2016.

Bayrakdaroglu, A., Ersay, E., Citak, L. (2012). "Is There A Relationship Between Corporate Governance and Value-Based Financial Performance Measures? A Study of Turkey as an Emerging Market”. Asia-Pasific Journal of Financial Studies (41). 224-239.

Beasley, M. (2004). "An Empirical Analysis of the Relation between the Board of Director Composition and Financial Statement Statement Fraud". The Accounting Review, 71: 443-465.

Bedard, J. Chtourou, S.M dan Courteau, L. (2004). "The Effect of Audit Committee Expertice, Independence, and Activity on Aggressive Earnings Management". Auditing, 23(2), 13-35.

Blume, M.E.,dan Keim, D.B. (2012). Institutional investors and stock market liquidity: trends and relationships. Diunduh dari SSRN 2147757 Desember 2012

Datta, S., Iskandar, D.M., Patel, A. (1999). "Bank Monitoring and The Pricing of Corporate Public Debt". Journal of Financial Economics, 51: 435-449.

Dechow, P., Sloan, R. \& Sweeney, A. (1996). "Causes and Consequences of Earnings Manipulation: an Analysis of Firms Subject to Enforcement Actions by the SEC". Contemporary Accounting Research, 13(1), 1-36. 
Diamond, D. (1984). "Financial Intermediation and Delegated Monitoring". Review of Economic Studies. 51: 393-414.

Dickins. D., Hillison, W., dan Platau, S. (2009). "Do Financial Statement Users Care about Differences in Board Members Source of Financial Expertise". The Journal of Applied Business and Economics. 9(2), 10-25.

Douthett, Edward B. Jr., dan Jung, K. (2001). "Japanese Corporate Grouping (Keiretsu) and the Informativeness of Earning". Journal of International Financial Management and Accounting. 12: 133-156.

El-Faitouri, R. (2014). "Board of Directors and Tobin's Q: Evidence from U.K. Firms". Journal of Finance and Accounting, 2(4), 82-99. Available online at http://pubs.sciepub.com/jfa/2/4/2 Science and Education

Fama, E.F., dan Jensen, M.C. (1983). "Separation of Ownership and Control”. Journal of Law and Economics, 26: 301-325.

Fama. E. (1985). What's Different about Banks. Journal of Monetery Economics, 15: 2939.

Fan, J. P. H dan Wong, T. J. (2002). "Corporate Ownership Structure and the Informative of Accounting Earnings in East Asia". Journal of Accounting and Economics, 33: 401- 425.

Feng C. Ole, K.H., Qinytuan L., dan Xin W. (2011). "Financial Reporting Quality and Investment Efficiency of Private Firms in Emerging Market". The Accounting Review, 86(4), 1255-1288.

Forum for Corporate Governance in Indonesia-FCGI. (2003). Indonesian Company Law. Diunduh 17 Januari 2015. www.fcgi.org.id.

Gabrielsen, G. Gramlich. J.D. dan Plenborg. T. (2002). Managerial Ownership Information Conten of Earnings and discretionary Accrual in non US Setting. Journal of Business Finance and Accounting, 29(7-8), 967-988.

Gideon, S.B Buediono. (2005). Kualitas Laba: Studi Pengaruh Mekanisme Corporate Governance dan Dampak Manajemen Laba dengan Menggunakan Analisis Jalur. Simposium Nasional Akuntansi VIII.

Gugong, B. K., Arugu, L. O., dan Dandago, K. I. (2014). "The Impact of Ownership Structure on the Financial Performance of Listed Insurance Firms in Nigeria". International Journal of Academic Research in Accounting, Finance and Management Sciences, 4(1), 409-416.

Gul. FA dan Wah, L.K. (2005). "Insider Entrenchment, Board leadhership Structure and Informativeness of Earnings". Diunduh tanggal 7 April 2015 dari http://ssrn.com.abstact=304399.

Habbash M., Christoph S., dan Aly S. (2013). "The Effect of Audit Committee Characteristicts on Earnings Management: Evidence from the United Kingdom". International Journal of Disclosure and Governance, 10(1), 13-38.

Hartono, J. (2005). Pasar Efisien Secara Keputusan. PT Gramedia Pustaka Utama, Jakarta,

Hassan U., Shedhu dan Abubakar, A. (2012). "Ownership Structure and Opportunistic Accounting: A Case of Listed Food and Beverage Firms in Nigeria”. International Journal of Physical and Social Sciences. 2(7), 236-256.

Hassan U.dan Shehu. (2013). "Financial Reporting Quality, Does Monitoring Characteristics Matter? An Empirical Analysis of Nigerian Manufacturing Sector". The Business \& Management Review. 3(2), 147-161 
He, W., Li, D., Shen, J., dan Zhang, B. (2013). Large foreign ownership and stock price informativeness around the world. Journal of International Money and Finance, 36, 211-230.

Hsu, M.F., dan Wang, K. (2014). The level and stability of institutional ownership and firm performance: Evidence from Taiwan. Emerging Markets Finance and Trade, 50, 159-173.

Jao, R dan Pagalung, G. (2011). "Corporate Governance, Ukuran Perusahaan, Dan Leverage Terhadap Manajemen Laba Perushaan Manufaktur Indonesia”. Jurnal Akuntansi dan Auditing. 8 (1), 1-94.

Jensen, M. C dan Meckling, W. H. (1976). Theory of the Firm: Managerial Behavior, Agency Cost and Ownership Structure. Journal of Financial Economics, 3(4): 305360.

Krisnan, G. V. dan Visvanathan, G. (2009). "Do Auditor price Audit Committee's Expertice?. The Case of Accounting versus non accounting financial experts". Journal of Accounting, Auditing and Finance, 24(1), 115 -125

Leland, H. dan Pyle. D. (1997). "Information Asymmetries, Financial Structure and Financial Intermediation". Journal of Finance, 32: 371-387.

Liris, M.L. (2013). "Pengaruh Kepemilikan Ultimat Terhadap Praktik Classification Shifting (Studi pada Perusahaan Manufaktur yang Terdaftar di BEI". Jurnal Ilmiah Akuntansi. 1-15.

McMullen, D. A., dan Raghunandan, K. (1996). "Enhancing Audit Committee Effectiveness". Journal of Accountancy, 182 (2): 79-81.

Moh'd M.A, Perry L.G, dan Rimbey J.N. (1998). “The Impact of Ownership Structure on Corporate Corporate Debt Policy: A Time Series Cross-Sectional Analysis". The Financial Review, 33: 85-98.

Mohamed, NF., Ahmad, K, dan Ji, X.D. (2011). Accounting Conservatism, Corporate Governance and Political Influence: Evidance from Malaysia. http://ssrn.com:1716485. September 2011

Naimah, Z., dan Utama, S. (2006). "Pengaruh Ukuran Perusahaan, Pertumbuhan, dan Profitabilitas Perusahaan terhadap Koefisien Respon Laba. Studi pada Perusahaan Manufaktur di Bursa Efek Jakarta". Simposium Nasional Akuntansi IX.

Nugroho Y.B. dan Umanto, E. (2012). "Board Characteristics an Earning Management". Journal of Administrative Science \& Organization, 18, 1-10.

Prastiti, A dan Wahyu M. (2013). Pengaruh Karakteristik Dewan Komisaris dan Komite Audit terhadap Manajemen Laba. http://ejournal-s1.undip.ac.id/index.php/ accounting

Putra, W.M. (2008). "Perlindungan Investor Pasar Modal dalam Perspektif Legal, Disclousure dan Dividen di Beberapa Negara". Jurnal Akuntansi dan Investasi, 9(1), 66-79.

Raghunandan, K. dan Rama, D.V. (2007). "Determinants of Audit Committee Diligence". Accounting Horizons, 21(3), 265-279.

Ratnadi, NMD.,Sutrisno T.,Achsin, M., Mulawarman, A.D. (2013). "The Effect of Shareholder' Conflict Over Devidend Policy on Accounting Consevatism: Evidence from Public Firms in Indonesia". Research Journal of Finance and Accounting, 4(6), $145-155$ 
Rose, A.M dan Rose, J.M. (2008). "Management Attempts to Avoid Accounting Disclosure Oversight: The effect of Trust and Knowledge on Corporate Dirctor's governance Ability". Journal of Business Ethics, 83(2), 1993-205.

Salehi, M., Hematfar, M. dan Heydari, A. (2011). "A study of the relationship between institutional investors and corporate value: empirical evidence of Iran". Middle-East Journal of Scientific Research, 8 (1), 72-76

Shabbir, S. S. (2012). "The Role of Institutional Shareholders Activism in the Corporate Governance of Pakistan". Journal of Humanistic and Social Sciences, 1 (2), 1-23

Shleifer, A. dan Vishny, R.W. (1997). A Survey of Corporate Governance". The Journal of Finance LII, (2): 737-783.

Subekti, I. (2012). Relevansi Nilai Atas Informasi Akuntansi, Struktur Kepemilikan Saham, dan Afiliasi Group Bisnis Pada Perusahaan Publik Di Indonesia. Simposium Nasional Akuntansi $X V$. Universitas Brawijaya

Sun, J., dan Guoping, L. (2013). Auditor Industry Specialization, Board Governance, and Earnings Management. http://scholar.uwindsor.ca/ odettepub. Diakses tanggal 30 Januari 2016.

Tahir, S.H., Saleem, M., dan Arshard, H. (2015). "Institutional Ownership And Corporate Value: Evidence From Karachi Stock Exchange (Kse) 30-Index Pakistan”. Praktični menadžment. VI (1), 41-49

Thanatawee, Y. (2014). "Institutional Ownership and Firm Value in Thailand." Asian Journal of Business and Accounting 7(2).

Wang, C., Xu, H., Scott, N., dan Ding, P. (2014). "Influence of Institutional Investors on Listed Tourism Companies' Performance: An Empirical Case from China”. Journal of China Tourism Research, 10 (3), 257-274

Wawo, A. (2010). Pengaruh Corporate Governence dan Konsentrasi Kepemilikan Terhadap Daya Informasi Akuntansi. SNA XIII. Purwokerto.

Widyati, M.F. (2013). "Pengaruh Dewan Direksi, Komisaris Independen, Komite Audit, Kepemilikan Manajerial Dan Kepemilikan Institusional Terhadap Kinerja Keuangan”. Jurnal Ilmiah Manajemen. 1(1)

Wiranata, Y.A., dan Nugrahanti, Y.W. (2013). "Pengaruh Struktur Kepemilikan Terhadap Profitabilitas Perusahaan Manufaktur di Indonesia". Jurnal Akuntansi dan Keuangan. 15(Mei): 15-26.

Woidtke, T dan Yeh, Y. H. (2013). "The Role of the Audit Committee and Yhe Informativeness of Earnings in East Asia". Pasific-Basin Finance Journal. 23(Juni):1-12

Xie, B., Davidson, W.N. dan DaDalt, P.J. (2003). "Earnings Management and Corporate Governance: The Role of the Board and the Audit Committee". Journal of Corporate Finance, 9: 295 - 316.

Yeo, G.H.H., Tan, P.M.S, Ho, K.W., dan Chen, S. (2002). "Corporate Ownership Structure and the Informativeness of Earnings". Journal of Business Finance dan Accounting. 29(7-8), 1023-1046. 